\title{
38. THE FRAMEWORK OF DEFORMATION IN THE NANKAI TROUGH ${ }^{1}$
}

\author{
D. E. Karig, Department of Geological Sciences, Cornell University ${ }^{2}$
}

\begin{abstract}
Drilling data and processed reflection profiles permit a quantitative description of deformation across the toe of the accretionary prism behind the Nankai Trough. Deformation begins in a 5-km-wide protothrust zone, where trench-fill strata are tectonically thickened and uplifted, both by diffuse mechanisms and along $60^{\circ} \mathrm{N}$ dipping seismic discontinuities. This zone is bounded arcward by the frontal thrust, which displays the characteristics of a bedding-plane step thrust, including a $30^{\circ} \mathrm{ramp}$ above which a hanging-wall anticline has formed. A balanced section of the fault zone shows $280 \mathrm{~m}$ of horizontal shortening, except along the uppermost flat section, where the thrust merges with a sediment apron built largely of material slumped from the thrust toe. Both the frontal thrust slice and the one behind it show an arcward increase in diffuse deformation and internal, now inactive thrusts of large $(\geq 1 \mathrm{~km})$ displacement. Cumulative deformation becomes greater toward the arc until the section loses seismic coherence. Total horizontal shortening estimated from structural geometries across the seawardmost $15 \mathrm{~km}$ of the accretionary prism is estimated as near $8 \mathrm{~km}$. The style of deformation in this setting is that of foreland thrust belts, not recumbent folding as previously suggested. Thrusts initially form at intervals near $3 \mathrm{~km}$, but some quickly deactivate, resulting in compound thrust sheets 5 to $7 \mathrm{~km}$ in width, each having a wedge-shaped cross section.

Modeling of the distribution of deformation with the methods of continuum mechanics produces results very similar to those from the structural analysis. The instantaneous distribution of deformation permitted by this approach indicates that one third of the subduction rate is absorbed within the protothrust zone and three fourths within the $15 \mathrm{~km}$ of prism toe that was analyzed. The remaining fraction of the instantaneous deformation is distributed across the lower trench slope in the form of continued arcward rotation of strata and isoclinal folding, as observed in emergent sections of the prism along the south coast of Shikoku. The continuum relationships, together with constraints on the age of deformation resulting from DSDP Leg 87 , generate a subduction rate of $2 \mathrm{~cm} / \mathrm{yr}$. or less.
\end{abstract}

\section{INTRODUCTION}

As more is learned about the characteristics of active plate margins, the focus of interest is turning toward the processes responsible for deformation in that setting and for variation in subduction histories. This focus requires increasingly intensive and sophisticated investigations of active trench systems. One such investigation was done on Leg 87A of the Deep Sea Drilling Project, which had as its principal objective the investigation of structural, physical, and mechanical properties associated with the initial phases of subduction at the foot of the inner slope of the Nankai Trough (Fig. 1). Despite the lack of accomplishment of much of the proposed program, the drilling data, in conjunction with several highly processed reflection profiles, permit a number of conclusions and implications to be drawn concerning subduction and deformation in the Nankai Trough.

The Nankai Trough is a relatively shallow trench, primarily because shallow, young Miocene crust of the Shikoku (back-arc) Basin is being subducted. The sediment section entering the trench in the vicinity of the drill sites consists of $750 \mathrm{~m}$ of hemipelagites and distal turbidites deposited in the Shikoku Basin, overlain by a wedge of trench-fill sediments about $16 \mathrm{~km}$ wide and $700 \mathrm{~m}$ thick at the base of the inner slope (Fig. 2).

\footnotetext{
${ }^{1}$ Kagami, H., Karig, D. E, Coulbourn, W. T., et al., Init. Repts. DSDP, 87: Washington (U.S. Govt. Printing Office). 14853.
}

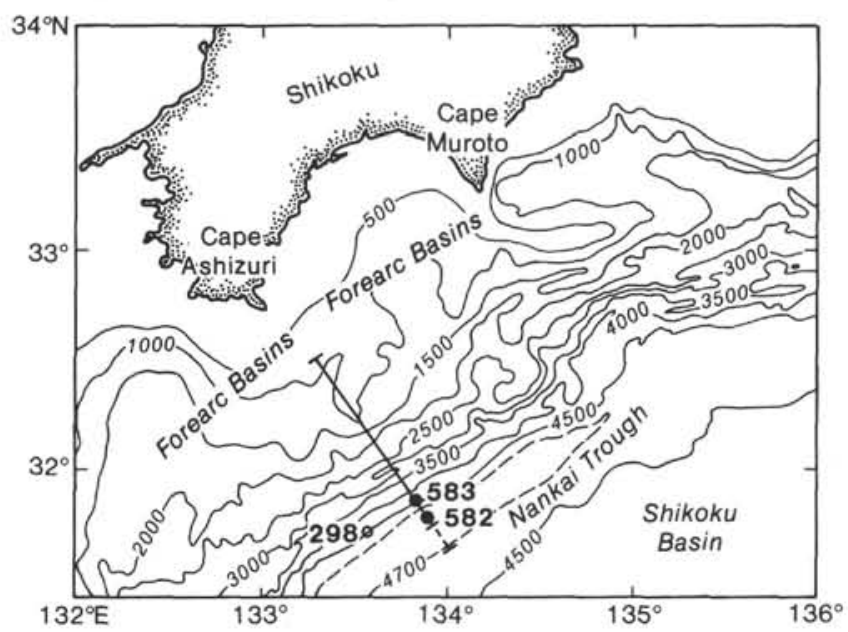

Figure 1. Regional setting of DSDP Leg 87 in the Nankai Trough. The heavy solid line shows the location of the reference seismic reflection profile, part of which is shown in Figures 2 and 4 . The dashed southerly extension of this line locates the seismic profile obtained by the Glomar Challenger and is shown in Figures 2 and 3. Water depth is in meters.

Seismic reflection profiles have revealed that subduction-related deformation begins well to the southeast of the base of the steep inner slope of the Nankai Trough, in a protothrust zone about $5 \mathrm{~km}$ wide (Figs. 2, 3). Over this zone, deformation gradually increases arcward, until trench-fill strata are uplifted nearly $150 \mathrm{~m}$ above the trench fill.

The arcward boundary of this zone of incipient deformation is marked by the first major thrust fault, which 


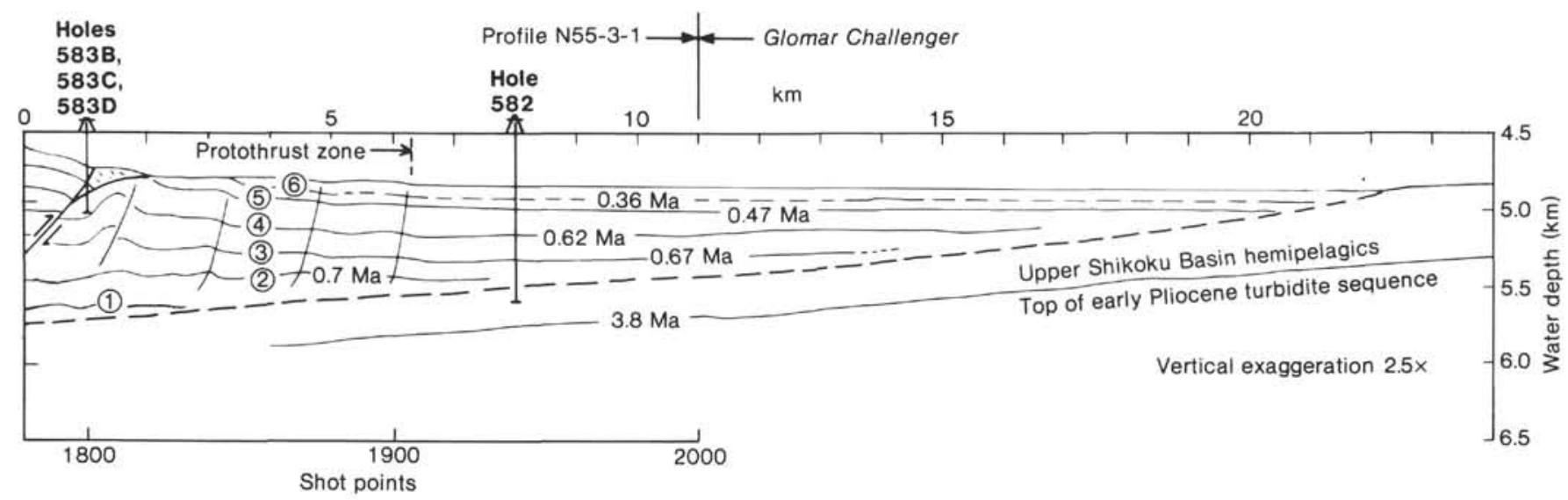

Figure 2. Cross section of the sediment fill in the Nankai Trough constructed from the depth section of the reference profile and from the unprocessed Glomar Challenger seismic time section, both located in Figure 1 and shown site chapter, Site 582 (this volume). The latter profile was converted to a depth section using interval velocities from DSDP Sites 297 and 582. Only the dated reflectors (circled numbers) used for calculations in this study are shown. The frontal thrust is shown surfacing near SP 1800. (SP = shot point numbers.)

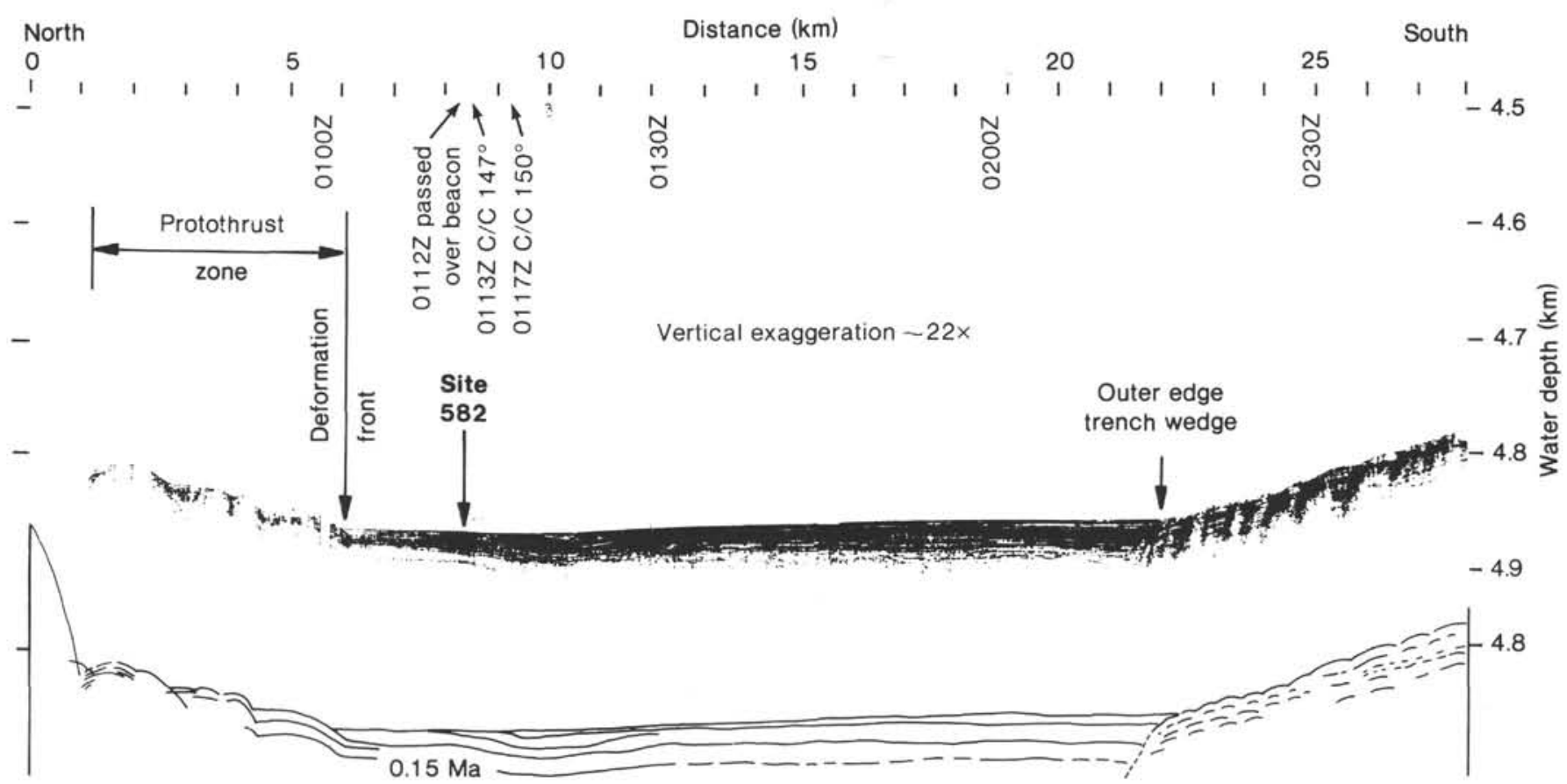

Figure 3. Glomar Challenger 3.5-kHz profile and interpretive section across the Nankai Trough. Note the successive onlap of trench-fill strata against hemipelagic strata at the deformation front and within the protothrust zone. The horizontal distance scale is the same as that used in Figure 2. $(\mathrm{C} / \mathrm{C}=$ course change. $)$

lifts trench sediments to form a structural terrace (Fig. 4). This and older more interior thrusts rise from a décollement that lies within the sedimentary section. The lower trench slope is composed of a series of structural terraces, which display a rapid arcward decrease in acoustic coherence, suggesting an arcward increase in cumulative deformation. These terraces can be traced for more than $50 \mathrm{~km}$ along strike in the vicinity of the drill sites and show a remarkable linearity and parallelism. This well-organized, two-dimensional geometry thus presents an excellent situation for analyses of the rate, distribution, and style of deformation.
The purpose of this chapter is to address several aspects of deformation on the lowermost slope elucidated by the results of DSDP Leg 87 . These include the amount and nature of deformation across the protothrust zone, the geometry of deformation beneath the lowermost slope, and the distribution of deformation across the entire lower slope.

\section{PROTOTHRUST ZONE}

In the protothrust zone, trench-fill strata progressively thicken arcward, concomitant with their uplift above the trench floor. The protothrust zone is also character- 


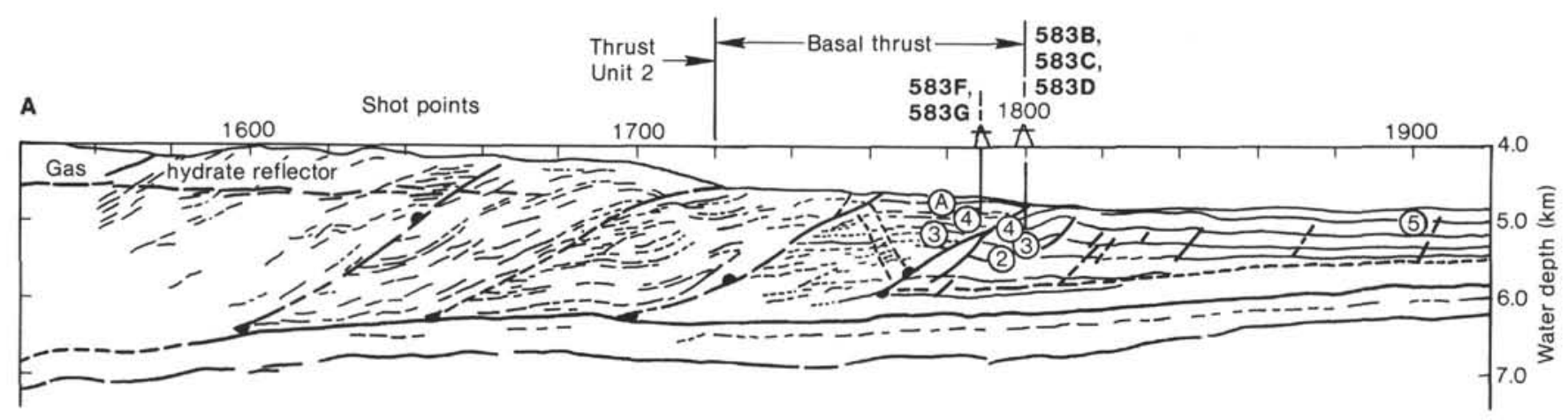

B

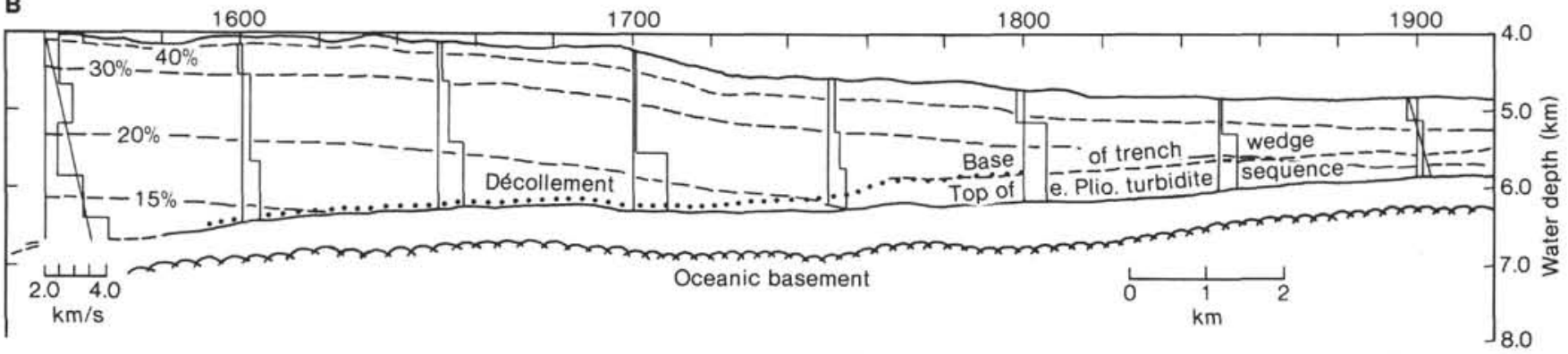

Figure 4. A. Interpretive depth section across the toe of the Nankai accretionary prism, from seismic Profile 55-3-1 (Nasu et al., 1982). The displaced half circles represent estimates of offset along major thrust faults. The labeled reflectors are the same as shown in Figure 2. B. Interval velocities (from Nasu et al., 1982); linear velocity gradients, derived from interval velocities, refraction velocities (Yoshii et al., 1973), and drilling results; and porosities (percentages), converted from velocities using relationships of Hamilton (1978), across the prism toe.

ized by a series of steep $\left(60^{\circ}\right)$ arcward-dipping seismic discontinuities that extend downward through the trench fill to die out near the contact with the Shikoku basinal strata (Figs. 2, 4). The larger of these discontinuities, the structural nature of which are not resolved by reflection profiling, are approximately $1.5 \mathrm{~km}$ apart, with displacements that increase arcward to more than $50 \mathrm{~m}$ (Fig. 2). The protothrust zone probably begins about $2 \mathrm{~km}$ northwest of DSDP Site 582 with a $20-\mathrm{m}$ step or flexure (Fig. 3). A subtle $10-\mathrm{m}$ flexure, about $1 \mathrm{~km}$ south of Site 582 may represent incipient deformation, or it may merely be part of a compaction-related sag in the trench fill, because deflection disappears at depth. On the other hand, the clearly defined deformation front extends downward through the entire trench fill.

At the deformation front the uppermost trench turbidites lap onto and/or change facies to hemipelagic deposits (Fig. 3). At the rear edge of the protothrust zone, at least $40 \mathrm{~m}$ at the top of the trench-fill section are missing or very highly condensed. Replacement of turbiditic by hemipelagic sediment appears to be concentrated at steps about $1.5 \mathrm{~km}$ apart, a spacing that coincides with the more prominent of the structural discontinuities.

In contrast to the arcward thinning of the uppermost turbidites, all deeper units in the trench wedge display an arcward thickening across the protothrust zone. This thickening could be caused either by the tectonism responsible for deformation and uplift of the trench fill or as a result of the continuous arcward increase in dip of the descending plate (Hsü and Ryan, 1972). The amount of thickening caused by the increase in plate dip is de- pendent on rates of deposition and subduction and also on the differential compaction of a wedge-shaped sediment body. This arcward thickening should vary with respect to rates of deposition and subduction, but should be intrinsic to trench deposition.

The geometry of the trench strata within the protothrust zone, then, should be a result of both structural and depositional processes. Effects of these different processes must be separated and quantified before estimates of strain and total deformation can be made. In particular, the arcward thickening attributable to deposition must be deduced. This assessment is done here both from observations of strata south of the deformation front and from calculation of the expected thickening with a previously determined subduction rate, using reasonable compaction-depth relationships.

One of the more surprising observations drawn from the Glomar Challenger seismic profile across the entire trench wedge (Fig. 2) is the apparent lack of arcward dips within the trench wedge. Although this analog time section could not be processed or interpreted to the extent possible on the reference seismic profile, the conclusion that average arcward dips south of the deformation front are less than $1^{\circ}$ cannot be avoided. Local zones of low dip, both arcward and basinward, occur within the trench wedge, but these can be interpreted as effects of differential compaction related to irregularities of the descending plate. The most prominent of these dip effects is caused by the rapid compaction of the Shikoku Basin strata beneath the southern edge of the trench fill (site chapter, Site 582, this volume). This process has resulted in a slight basinward dip of the surficial turbidites 
(Fig. 3), but a more pronounced arcward dip of the deeper turbidites deposited over this rapid compaction zone (Fig. 2). The lack of significant arcward thickening of strata across the undeformed section of the trench wedge provides the strongest and most direct evidence that most of the stratal thickening across the protothrust zone is of structural origin.

Arcward stratal thickening, resulting from the geometry of the subduction process, can be calculated by the relation

$$
\theta=\left(\frac{360}{2 \pi \mathrm{R}} \frac{\Delta \mathrm{L}}{\Delta \mathrm{t}}\right) t
$$

(Hsü and Ryan, 1972; Karig and Angevine, this volume). In this relationship $\Delta \mathrm{L} / \Delta \mathrm{t}$ is the average subduction rate, which was deduced by Karig and Angevine (this volume) to be near $2.0 \mathrm{~cm} / \mathrm{yr}$., $\mathrm{R}$ is the average radius of curvature of the descending plate near the drill sites $(850 \mathrm{~km}$; Karig and Angevine, this volume), and $t$ is the age of the stratum having a dip of $\theta$. For this and all subsequent calculations, six prominent reflectors within the trench wedge were identified and dated (Fig. 2). The oldest (Reflector 1), which occurs only beneath the protothrust zone, is assigned an age of 1 Ma by extrapolation downward from the oldest trench strata penetrated at Site 582 at a sedimentation rate of $900 \mathrm{~m} / \mathrm{Ma}$ (site chapter, Site 582 , this volume). If only the effects of subduction geometry are considered, the dip of Reflector 1 should be about $1.0^{\circ}$.

Differential compaction, increasing arcward as the sediment column beneath a given stratum becomes thicker, will further increase the arcward dip by reducing the original arcward thickening of stratigraphic intervals. This effect can be adequately estimated by fitting an exponential porosity $(n)$-depth $(y)$ relationship (e.g., Athy, 1930) to porosity data measured in samples from trench wedge at Site 582:

$$
n=\mathrm{n}_{0} \mathrm{e}^{\left(\frac{-y}{\mathrm{y}_{\mathrm{L}}}\right)}
$$

where $\mathrm{n}_{0}$ is the porosity of surficial sediment, and $\mathrm{y}_{\mathrm{L}}$ is a constant, characteristic of the sediment section. This relationship is applied to the stratum under consideration in both its present and original (time of deposition) configurations to determine change in thickness of the compressible sediment beneath that stratum. Equating the volume of the sediment fraction of this underlying stratal section at the two times, $\mathrm{t}_{0}$ and $t$,

$$
\int_{0}^{y_{\mathrm{boo}}}\left(1-\mathrm{n}_{0} \mathrm{e}^{\left(\frac{-y}{\mathrm{y}_{\mathrm{L}}}\right)}\right) \mathrm{d} y=\int_{\mathrm{y}}^{\mathrm{y}_{\mathrm{b}}}\left(1-\mathrm{n}_{0} \mathrm{e}^{\left(\frac{-y}{\mathrm{y}_{\mathrm{L}}}\right)}\right) \mathrm{d} y
$$

where $y$ is the depth to the stratum and $\mathrm{y}_{\mathrm{b}}$ is the depth to basement. The difference in $y_{b}$ is the compaction at one point along the trench-fill section; differences in compaction between two points, separated by a known distance, leads to the compaction-induced dip.

This calculation is complicated by the fact that porosity data from Site 582 and for other terrigenous sec- tions are strongly biased toward the more compressible clay-rich lithologies; the sand-rich units are poorly recovered, highly disturbed, and difficult to sample. Welllogging results at Site 583 demonstrate that the trench fill is dominated by sand-rich units that have significantly lower porosities and less change in porosity with depth than do the clay-rich units. For the calculation of differential compaction, the trench fill has been assumed to consist of $50 \%$ sand-rich and $50 \%$ clay-rich sediments, which typifies the logged section of Site 583 (site chapter, Site 583, this volume). For the Nankai Trough fill, $n_{0}=0.65$ and $y_{\mathrm{L}}=0.65 \mathrm{~km}$. The porosity values used to determine these constants were either in situ logging results or laboratory values corrected for rebound (Hamilton, 1976; Shepard and McMillen, 1982). The underlying Shikoku Basin section can more confidently be approximated by clay-rich sediments. These show almost no differential compaction beneath the protothrust zone.

These values, together with the geometries obtained from the combined seismic depth profile, result in a compaction-generated dip of $1.3^{\circ}$ at Reflector 1 . The dip, calculated for combined plate bending and compaction effects at this reflector is $2.3^{\circ}$, which is to be compared with an observed $1.6^{\circ}$. This discrepancy could be reduced if structural thickening of the section beneath Reflector 1 had reduced its observed dip, but the depth interval to the décollement, beneath which there is no apparent deformation, is too small to absorb much thickening. The discrepancy between expected and observed dips is at least as large for the shallower reflectors at positions south of the deformation front. Less compressible (sandier) sediments and a slower subduction rate than assumed would also reduce the discrepancy.

A more direct approach by which to determine the division of causes for the thickening of the section is to assume that structural thickening must be at least as great as the uplift of an initially horizontal turbidite stratum. Between shot point (SP) 1795 on the reference profile (at the rear of the protothrust area: Fig. 4) and SP 1910 (at the deformation front), Reflector 4 shows $140 \mathrm{~m}$ of uplift; this is a minimum value for total structural thickening because Reflector 5 is not present at SP 1795. If bending of the lower plate has caused the arcward tilt of Reflector 1, its $50-\mathrm{m}$ arcward depression agrees fairly well with the expected depositional thickening. The total thickening of the section between Reflectors 1 and 4 is more than $170 \mathrm{~m}$. Reflector 1 does not extend to the deformation front, but if the same strain pattern can be projected to the deformation front, an additional $30 \mathrm{~m}$ of total thickening can be estimated. Considering the uncertainties involved, the structural component of thickening of the trench wedge across the protothrust zone is estimated to be between 150 and $160 \mathrm{~m}$.

With this conclusion and the following approximations, horizontal shortening within the protothrust zone can be calculated. Because the reference frame of the seismic profile represents the deformed state of the stra$\mathrm{ta}$, it is easier and more illustrative to determine deformation in the observable reference frame. Thus, instead of strain (which is referred to the undeformed state of the material), I define deformation in terms of a related 
parameter, here termed shortening ratio $\left(\phi=\Delta \mathrm{L} / \mathrm{L}_{\mathrm{d}}\right)$, in which the reference dimension is the deformed length $\left(\mathrm{L}_{\mathrm{d}}\right)$. Strain $(\epsilon)$ is derived from the shortening ratio $(\phi)$ using the function of stretch $(S)$, which is the ratio of deformed to original length $\left(\mathrm{L}_{\mathrm{d}} / \mathrm{L}_{0}\right)$ (Means, 1976). In this treatment the definition of strain is modified to be positive during shortening, so that $S=1-\epsilon$. In terms of $S$, the shortening ratio is

$$
\phi=\frac{1-S}{S}
$$

Combining these two equations produces the relationship: $\epsilon=\phi S$. Because $S$ has values between 0 and 1 for shortening, $\epsilon \leq \phi$.

The vertical shortening ratio is assumed to increase linearly arcward across the protothrust zone. This seems reasonable in that the uplift of each reflector across the zone appears linear. In reality, the thickening may be concentrated at the steeply dipping discontinuities, because there are very small but measurable increases in thickness across these structures. Thickening does not appear to be uniform with depth, but this may be a function of varying fractions of structural and depositional effects. For example, at the rear of the zone vertical thickening appears to decrease upward between Reflectors 4 and 5, but this decrease probably reflects arcward depositional thinning. Vertical thickening appears largest at mid-depths, between Reflectors 2 and 3. There is no evidence of deformation below the trench wedge. This conclusion is based on (1) a lack of arcward thickening of any of the Shikoku Basin strata, (2) absence of structural discontinuities, and (3) a uniform arcward parallelism of dips in all horizons down to the basement reflector. For the following calculation of horizontal shortening ratio and total shortening, uplift of the trench fill is attributed to vertically uniform and arcward linearly increasing deformation. The assumption of vertically uniform thickening is, in effect, a fit to the average of observed values. Vertical shortening ratio $\left(\phi_{y}\right)$ at SP 1795 (Fig. 4) is 0.185 , where elongation is defined as negative.

The horizontal shortening ratio is easily computed in this case of assumed plane strain and constant volume. In reality the slight arcward increase in porosity-depth gradient (Bray and Karig, this volume), together with the structural thickening, would lead to greater horizontal shortening for a given vertical shortening ratio. However the more complicated, variable volume solution is not yet warranted by the available data. Thus, $\phi_{x}=$ $-\phi_{y} / 1+\phi_{y}$, which, evaluated at SP 1795 , is 0.227 . If the horizontal shortening ratio increases linearly across the protothrust zone, then $\phi_{\mathrm{x}}=0.227 x / \mathrm{X}$ where $\mathrm{X}$ is the width of the protothrust zone, and the total shortening

$$
(\Delta \mathrm{L})=\int_{0}^{\mathrm{X}} \frac{0.227}{\mathrm{X}} x \mathrm{~d} x \text {. }
$$

With a width (X) of $5.75 \mathrm{~km}$ for the protothrust area, $\Delta \mathrm{L}=650 \mathrm{~m}$. To this distributed strain must be added approximately $50 \mathrm{~m}$ shortening on the discrete fold-thrust near SP 1810, the effects of which were not included in the preceding calculation, producing a total shortening of about $700 \mathrm{~m}$.

\section{FRONTAL THRUST SHEET}

The protothrust zone is sharply terminated on its arcward flank by the development of the frontal thrust fault (Figs. 2, 4). This feature bounds the most recent slice of trench fill accreted to the Southwest Japan Arc and has lifted this slice into a terracelike configuration. The thrust rises upward at an angle close to $30^{\circ}$ from the décollement zone, which at that point (SP 1765, Fig. 4) lies $200 \mathrm{~m}$ above the Pliocene turbidite sequence. Slightly below the level of Reflector 5 in the footwall (Fig. 2), the fault surface flattens sharply upward into bedding, defining the top of a ramp or riser.

The shallowest segment of the fault surface is not well defined by seismic or drill data, but appears to be subhorizontal and to surface at the foot of a 80-m-high topographic scarp (Fig. 5). As discussed later, this upper flat section is a thrust fault near the ramp corner, but southward becomes the lower boundary of a slump deposit generated from the toe of the thrust sheet. Thus, there may be less, even no, differential movement along the flat section of the fault where it surfaces. This horizontal boundary locally cuts downsection in the direction of thrusting because of the small fold-thrust in the footwall (Fig. 5). The implication is that the footwall structure formed and was eroded before being covered by the basal thrust and slump.

The geometry over the upper $700-800 \mathrm{~m}$ of the trace of the frontal thrust is well defined by seismic and drill data (Fig. 5). Above the ramp, the hanging-wall strata show no observable folding. Any drag effects adjacent to the fault would have to be smaller than the seismic resolution and lie within the estimated 20-50-m-thick undrilled interval above the fault. Over the top of the ramp, however, and southward of the upper ramp corner the strata in the hanging wall form a south-dipping monocline, with dips of 25 to $50^{\circ}$. Folding in this setting, contrasted with lack of disturbance along the deeper sections of the thrust, can be explained by development of a hanging-wall anticline over the upper corner of the thrust ramp. A small-displacement fault splay, defined in the hanging-wall block by the base of the steep slope and by very steep $\left(>60^{\circ}\right)$ local dips in Hole $583 \mathrm{D}$, could be described as a hanging-wall imbricate. Thus, despite the relatively incompetent nature of the strata involved, the geometry of deformation here resembles that of the bedding-plane step thrusts that have been observed and thoroughly studied in foreland thrust belts (e.g., Dahlstrom, 1977). Because of this general similarity, the analysis of the frontal thrust begins with the same assumptions applied to foreland thrust belts: conservation of cross-sectional area and bedding parallel slip.

Total slip and slip components on the frontal thrust can be estimated from the seismic profile and from drill data with reasonably consistent results. In Hole 583D, the NN19/NN20 nannofossil boundary was placed $130 \mathrm{~m}$ lower in elevation than in Hole 583 (site chapter, Site 


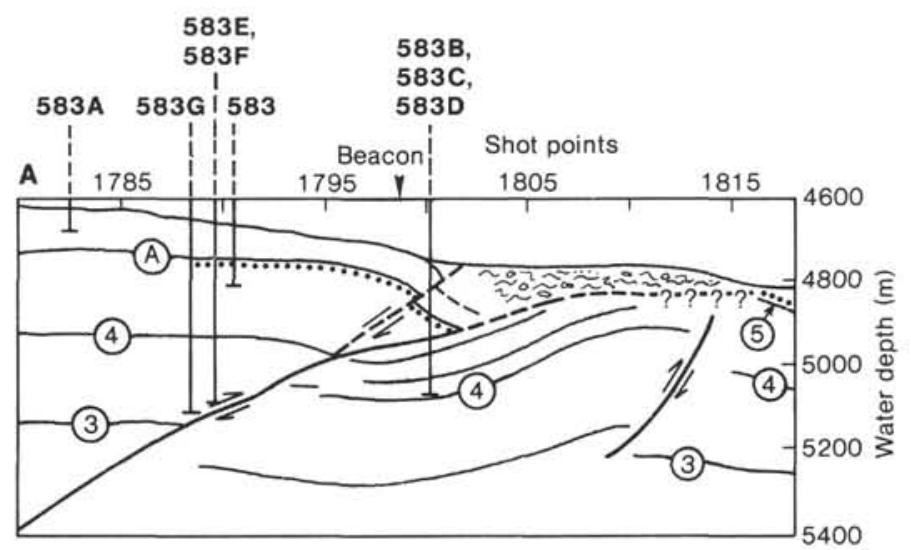

B

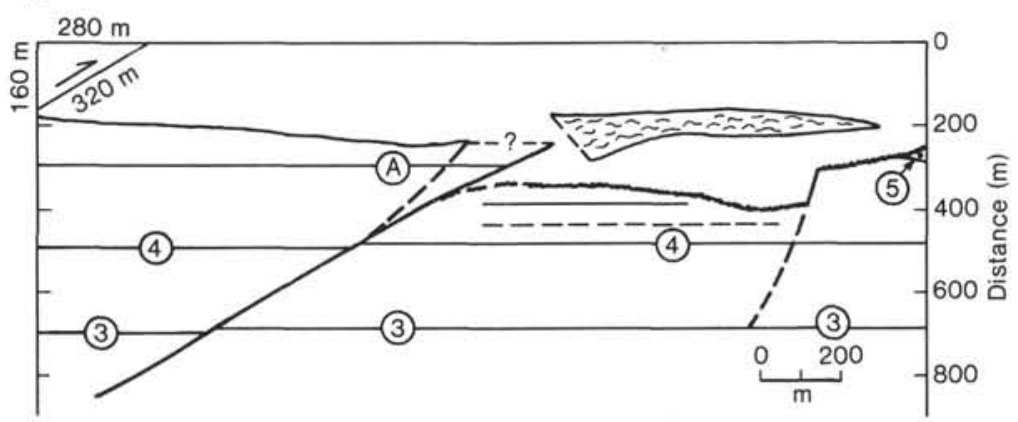

Figure 5. A. Balanced structural section across the frontal thrust fault and associated structures, constructed from drilling results and the seismic depth sections. B. Restored section across the frontal thrust illustrating the surficial areas of imbalance, most of which is identified as a slump apron. The dotted line below Reflector A and above Reflector 5 marks the NN19/20 nannofossil boundary. The diffuse arcward increase in structural thickness of units was not modeled in the restored section because it is very irregular on this scale and does not significantly affect the calculated displacement on the frontal thrust.

583 , this volume), providing an apparent minimum vertical offset. With a local fault dip of $28^{\circ}$, the horizontal throw on the thrust should be more than $245 \mathrm{~m}$.

Stratal correlation across the fault is tentative because there is no unambiguous match of seismic reflectors and because no biostratigraphic or paleomagnetic boundaries could be carried from footwall to hanging-wall blocks. The most convincing correlation of seismic reflectors, based solely on pattern comparison, indicates a vertical displacement across the fault and its associated flexuring of between 150 and $160 \mathrm{~m}$ (Fig. 5A). The corresponding horizontal throw is $\sim 280 \mathrm{~m}$.

The structural section constructed from drilling and seismic data can easily be tested for balance by resorting the fault displacement (Fig. 5B). This process reveals that the total offset of the trench fill is accommodated by both discrete thrusting and by flexing of the footwall, and that the ratio of these two responses is not constant along the fault. The total vertical offset remains near $160 \mathrm{~m}$, most of which is absorbed by faulting at depths less than $300 \mathrm{~m}$. Below $300 \mathrm{~m}$ an increasing percentage of the total deformation is absorbed by apparent flexure of footwall strata. This flexure has flattened the thrust surface and is quite likely caused by a zone of footwall imbricate thrusts.
When displacements on both the thrust and flexure are restored, the fault surface returns to a $30^{\circ}$ dip (Fig. 5 ), and several minor problems emerge. The shallowest strata in the footwall are close to the level of Reflector 5 and correlate closely with Reflector A in the hanging wall. Probably, not too much more section ever existed on the footwall, because Reflector 6 disappears by onlap at a structural discontinuity near SP 1845 and, if the depositional pattern elsewhere in the protothrust zone can be used as a guide, Reflector 5 should disappear or nearly reach the sediment surface at the next large discontinuity near SP 1815. Another reason for doubting the original continuity of Reflectors A and 5 is that the NN19/NN20 nannofossil boundary occurs above Reflector 5 at Site 582 in the footwall and below Reflector A in the hanging wall (Fig. 5). These arguments lead to the identification of much of the strata above Reflector A in the hanging wall as slope sediments, deposited only on that block.

There are also two imbalances of area in the nose of the thrust. A small piece of footwall block is missing, but this is outbalanced by an excess area of hanging-wall block lying above the horizontal toe of the thrust surface. The missing footwall most likely was stripped off as a small footwall imbricate and now is incorporated 
within the excess hanging-wall mass. The larger hanging-wall mass excess is interpreted as a seismically and probably structurally chaotic mixture of footwall fragments and trench-fill sediment slumped from the nose of the hanging wall.

Another problem in the restored section is the steeply dipping surficial section penetrated in Hole 583B (Fig. $5 \mathrm{~A})$. These strata should have been deposited before most folding and thrusting occurred and thus be trench-fill sediments. However, the restored section places them high above Reflector A of the hanging wall and, by my earlier argument, they should be largely slope sediments. Several solutions can be suggested. The structure of this area could be more complex than assumed; trench-fill deposition may have persisted later than previously argued; or there may have been enhanced local deposition in front of the incipient thrust zone. Of these I favor the last, as it shows similarities with the structural development in the Sunda Trench (Karig et al., 1980).

If the interpretation of the frontal thrust as a bedding-plane step thrust is correct, there should be a second, arcward-facing flexure in the hanging wall above the base of the thrust ramp. Moreover, the hanging-wall strata should return to their original elevation arcward of this flexure. This arcward-facing fold, in near-quantitative dimensions, can be seen on the seismic profile between SP 1760 and 1770 (Fig. 4), although increasing deformation in this area has begun to degrade the coherence of the reflectors. The thrust ramp flattens into the bedding décollement near SP 1755, in upper part of the Shikoku Basin hemipelagic section (Fig. 4).

The thickness of the hanging-wall block increases arcward because the décollement surface dips $2^{\circ}$ northward and the sediment surface rises. This increase is in part structural and in part stratigraphic. The stratigraphic component, reflecting arcward thickening of the paleo-trench wedge, cannot continue indefinitely, even if the trench wedge formerly was larger than it is at present (Karig and Angevine, this volume). Arcward increase in thickness of slope sediments can make only a minor contribution to the thickening and is counteracted by any dewatering effects. The largest factor must be structural thickening of the thrust masses by internal deformation and by subcretion of material to its base. Subcretion would actually create a form of thrust duplex, but cannot have a significant effect because the décollement does not change stratigraphic level beneath the frontal thrust sheet. On the basis of the reflection data, internal deformation is interpreted to be the dominant cause of thickening. Because reliable seismic correlations cannot be carried completely across the thrust block, the quantitative control of deformation is largely lost. More reliance must be placed on extrapolation of processes from the protothrust zone, where rates of thickening and deformation are better defined.

If the dip of the facies boundary $(\alpha)$ between the trench fill and Shikoku Basin hemipelagic sediments could be extrapolated arcward at 2 to $2.5^{\circ}$, and if no arcward disappearance of surficial trench strata by onlap occurred, the maximum arcward stratigraphic thickening of trenchfill strata would be $40 \mathrm{~m} / \mathrm{km}$. On the other hand, the observed rate of thickening is about $100 \mathrm{~m} / \mathrm{km}$, which does not include displacement on the discrete thrust that surfaces near SP 1760.

Thickening caused by diffuse deformation is assumed to occur on numerous local structures, most of which are seismically irresolvable. I have conservatively assumed that the difference between maximum stratigraphic thickening and total thickening, which is $60 \mathrm{~m} / \mathrm{km}$, is a result of arcward structural thickening. This rate is nearly double the $35 \mathrm{~m} / \mathrm{km}$ rate of tectonic thickening attributed to the present protothrust zone, but is reasonable because the thickness of deforming material is about 1.5 times as great as in the protothrust zone and because the degradation of seismic coherence suggests greater deformation. If the thickening is distributed through the section, the horizontal shortening can be determined the same way as was done for the protothrust zone. In this case

$$
\phi_{x} \geq \frac{0.34}{\mathrm{~L}}
$$

and with a length (L) of $5 \mathrm{~km}$, the total horizontal shortening would be at least $600 \mathrm{~m}$.

Horizontal displacement along the discrete thrust at SP 1760 is interpreted as nearly $1 \mathrm{~km}$, despite the subdued surficial relief across this structure. This interpretation is based not only on the seismic reflection pattern, which suggests that over $1 \mathrm{~km}$ of arcward-tilted strata above the thrust ramp represents slip, but also on a comparison of depths of paleontologically determined horizons between Site 583, in the footwall of this fault, and Site 289 (Ingle, Karig, et al., 1975), in the hanging wall. The discrepancy between structural-paleontologic data and geomorphic evidence can be resolved by significant local erosion from the area above the hanging-wall anticline and by differential slope sedimentation. It also suggests that the thrust is not very active presently.

\section{THRUST SLAB 2}

The frontal thrust slab is backed by another thrust fault (surfacing at SP 1720), with much greater relief and displacement than those of the basal thrust (Fig. 4). Although seismic coherence in the second thrust slab is even further degraded, the characteristics of a beddingplane step thrust can still be clearly observed. Strata in the footwall are nearly horizontal, whereas those of the hanging wall almost parallel the $30^{\circ}$ fault surface, except near the upper ramp corner where another hanging-wall anticline is developed.

Total slip along the fault, matching the ramp base in the footwall with the correlative hanging-wall cutoff, is about $2.5 \mathrm{~km}$. The resultant horizontal shortening would be more than $2 \mathrm{~km}$. The deduced vertical component of displacement of $1.25 \mathrm{~km}$ far exceeds the $0.7-\mathrm{km}$ relief of the fault scarp, but the reflection profile supports the deduction that there has been significant erosion of the thrust toe.

This fault again appears to flatten upward into bedding of the footwall. The uppermost strata of the footwall appear to overlie deeper, steeper dipping strata in angular unconformity and may represent a section of slope 
deposits overridden by the thrust for a distance of more than $1 \mathrm{~km}$ (Fig. 4, SP 1720). If there is an active mass of slumped sediments at the toe of this thrust, it is much smaller than that at the toe of the basal thrust. At depth the fault flattens into the décollement, which remains at a level only slightly above the top of the lower Pliocene turbidites.

Arcward of this major thrust, the reflection character of the accretionary prism is even more degraded, and only short reflecting segments, indicating the modal dips, can be observed. Strata within the hanging-wall slab above the ramp have an average $20^{\circ}$ arcward dip, attributed to displacement along the footwall ramp. These reflectors flatten arcward of the ramp and appear terminated by yet another thrust that surfaces near SP 1665 (Fig. 4). If the flat-lying reflectors defining the base of the hanging-wall ramp of this thrust can be matched with the base of the footwall ramp, and if a bedding-plane stepfault interpretation remains valid, the displacement along the fault will be about $3 \mathrm{~km}$. The $40^{\circ}$ dip on this thrust logically reflects rotation of the footwall by the younger faults that lie below. In the hanging wall of this steeper thrust, only scattered reflectors with $30-40^{\circ}$ arcward dips can be identified.

Internal deformation between the thrust faults, within the second thrust sheet, cannot be calculated but may be estimated using several indirect methods. The decreased coherence of reflectors is evidence that local deformation in this area is even more intense than in the terrace below. The geometry of the interthrust areas suggests that the deformed section was originally thinner than its present $1.3-\mathrm{km}$ value. Loss of porosity might reduce the thickness by $10-20 \%$, but tectonic thickening ought to be greater than this if the behavior of the less deformed toe of the prism can be used as a guide.

We can reasonably assume that slices of trench fill originally not much thicker than those existing today were accreted to the toe of the trench slope as far back as SP 1600 . Based on the foregoing criteria, shortening within the second thrust sheet, from SP 1700 to 1600 , should be more intense than that in the basal thrust sheet and is estimated as at least $1000 \mathrm{~m}$.

The sum of the estimated shortening, both within the thrust blocks and along the larger discrete thrusts, is about $8 \mathrm{~km}$ (Fig. 6). Because estimates are conservative this value ought to be a minimum.

\section{MORE INTERIOR SECTIONS OF THE PRISM}

Arcward of SP 1600 , scattered reflectors, probably mirroring bedding, reach dips of $30^{\circ}$ (Fig. 4). The major change is a loss of reflectors below a depth of between 0.5 and $1.0 \mathrm{~km}$. This featureless area of the accretionary prism is probably a result of continued deformation of the accreted strata, producing an acoustically white and highly dispersive seismic character. Only shallow reflections are observed, most of which represent slope sediments. At SP 1500, there is a small slope basin (not shown) with a thrust-backed, rotated sediment wedge (Nasu et al., 1982) that documents continuing rotation of subjacent material. Although slope sediments on this and proprietary JAPEX profiles are sometimes moderately

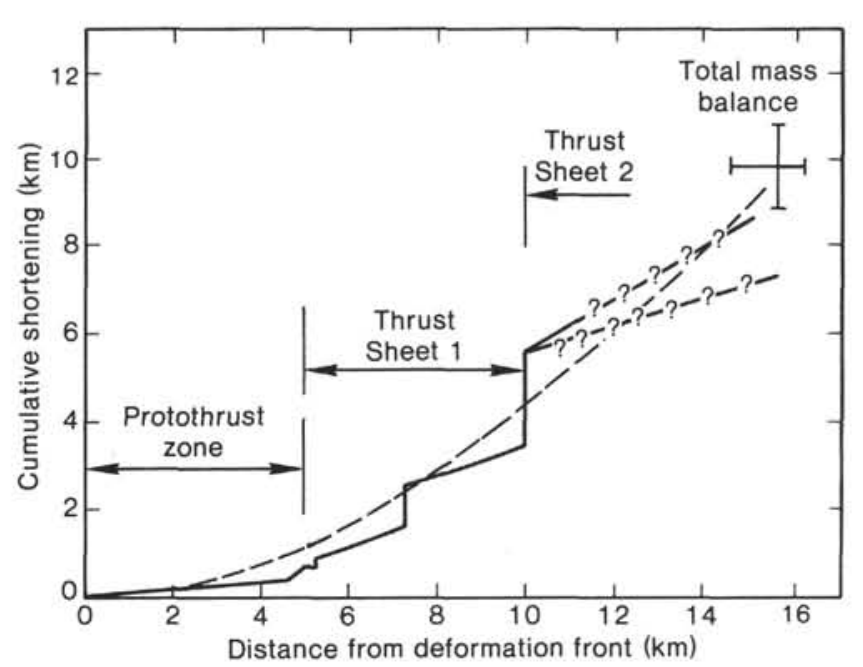

Figure 6. Cumulative horizontal shortening as a function of position $(x)$ across the toe of the Nankai accretionary prism. The solid line represents the sum of estimated shortening of individual thrust slices and displacement on the thrust faults. The dashed line represents the shortening derived from mass flow considerations and is also a smooth fit to the raw data (see text for details).

deformed, they generally show insufficient acoustic continuity to allow estimation of total deformation. However, the thick undeformed fill of the forearc basin (e.g., Nasu et al., 1982) precludes significant late Neogene deformation on the upper slope.

Some evidence for the intensity and nature of deformation between the point where acoustic control is lost and the upper slope can be derived from the nature of Paleogene to lower Miocene sediments of the Shimanto complex exposed on the Ashizuri and Muroto capes (Fig. 1 ). Both capes project southward into the zone of forearc basins. Outcrops include coherent sedimentary strata, some of which are probably slope deposits, and tectonic mélanges. Both of these types typically have very steep dips. These units become younger both northwesterly (arcward) and southeasterly, but the arcward-facing type is the most common. Field mapping (Taira et al., 1980,1982 ) and initial structural analysis (D. E. Karig and T. Byrne, unpublished data, 1984) suggest that these units have undergone tight, nearly isoclinal folding in addition to arcward rotation. If the processes responsible for deformation of these rocks are similar to those presently operative in the subduction zone, then strong rotation as well as subhorizontal shortening should dominate the deformation between SP 1600 and the forearc basin.

\section{DISTRIBUTION OF DEFORMATION BY MODELING}

Another approach to the distribution of deformation on the lower trench slope is the comparison of the observed geometry of the accretionary prism with that expected from various models of sediment input masses and distribution of deformation. Several variations of the method utilize the volume or thickness of the prism as a measure of horizontal shortening associated with accretion. To overcome the problem of volume changes 
caused by variations of porosity with the prism and trench fill, such comparisons require the use of the dense rock equivalent (DRE) volumes (Sigurdsson et al., 1980).

In this comparison we need control not only on the variation of the input supply with time, but also on the nature of the décollement along which material is transferred from the descending plate to the prism. The latter problem is solved by the reference seismic profile (Fig. 4), which shows that at the frontal thrust the décollement descends to a position just above the lower Pliocene turbidites and remains above these turbidites to at least SP 1350 (Nasu et al., 1982). This point is $12.5 \mathrm{~km}$ behind SP 1600 , which is a greater distance than the range of estimated total shortening in the prism seaward of SP 1600. Thus, between the frontal thrust and SP 1600 , there ought to have been very little transfer of material across the décollement. The input section, then, can be assumed to include, as a maximum, all the strata above the Pliocene turbidites.

This thickness at the present deformation front (SP 1900 ) is almost $1000 \mathrm{~m}$, with a DRE volume of 0.651 $\mathrm{km}^{3} / \mathrm{km}$ of arc length (henceforth stated as $\mathrm{km}^{2}$ ). The porosity data used to determine the DRE volumes are shown on Figure 4 and discussed by Bray and Karig (1985, and this volume). The input section used for modeling should be somewhat greater because the trench wedge has clearly been wider in the past (Karig and Angevine, this volume) and because each off-stripped slab thickens arcward. However, the seismically defined geometries of the accreted slabs led to the conclusion that the original thickness was not much greater than at present. We think that a constant input DRE volume of $0.8 \mathrm{~km}^{2}$ is a conservatively large estimate for accreted material back to SP 1600.

The calculation of volume distribution within the accretionary prism depends greatly on the porosities assumed for accreted sediments. These porosity values must be derived indirectly, in this case from seismic refraction and reflection data coupled with empirical seismic velocity versus density relationships.

Interval velocity profiles along the reference seismic section, which are individually quite variable, clearly show an arcward increase in the vertical velocity gradient (Fig. 4). Velocity profiles near SP 1300 compare quite well with the seismic refraction data along Profile 5 of Yoshii et al. (1973) at this position. Velocities within the prism in the vicinity of SP 1600 increase downward much faster than those in undeformed turbidite sections (e.g., Hamilton, 1980).

We estimated these velocities to increase linearly with depth, and the gradients to increase across the prism toe between control points at SP 1300 and the trench floor in a linear fashion. Velocities were then converted to in situ bulk densities using the curve of Hamilton (1978) for shale-rich clastics adjusted for the probable 1:1 sand: shale ratio as discussed by Bray and Karig (1985). Porosities were derived from bulk densities (assuming an average grain density of $2.7 \mathrm{~g} / \mathrm{cm}^{3}$ ) and plotted on the prism section (Fig. 4).

From the porosity plot, dense rock equivalent volumes can be calculated for columns $1 \mathrm{~km}^{2}$ in plan area, with which columns of input volume mass can be compared. Input volume is assumed to be a constant $0.8 \mathrm{~km}^{2}$ over the $27 \mathrm{~km}$ of descending plate along which the décollement remains above the Pliocene turbidites. This input of $22 \mathrm{~km}^{2}$ can be accommodated in the accretionary prism from SP 1900 to near SP 1550 . The geometry of the rear edge of the equivalent volume of deformed sediment is poorly defined because its dip is not known. I have assumed an arcward dip near $40^{\circ}$, parallel to the dip of the thrusts at this point. This exercise suggests that $27 \mathrm{~km}$ of incoming sediment now occupies an approximately $17-\mathrm{km}$-wide section of the accretionary prism, with a shortening near $10 \mathrm{~km}$ (Fig. 6).

It is difficult to suggest the error range in this value for shortening. Porosity values assumed are, if anything, too large, and increasing the amount of dewatering will result in larger values of shortening. If the paleotrench thicknesses were much greater than assumed, the shortening would decrease, but arguments have been presented countering this assumption. Up to several $100 \mathrm{~m}$ of high-porosity slope sediments could be subtracted from the observed prism section, which would reduce calculated shortening, but it is likely that much of this material was derived from the erosion of accreted sediments. Replacement of eroded sediments that were transported to the trench floor would only increase calculated shortening.

Another method to estimate shortening is to examine the arcward thickening of the prism, taking into account the volume loss caused by dewatering. This involves a comparison of the widths of columns of incoming and accreted sediments having identical DRE volumes, with the assumption of plane strain. Horizontal shortening thus calculated reflects both dewatering and tectonic thickening, but because both processes contribute to total shortening, the geometry of dewatering need not be determined. Horizontal shortening ratios of individual columns $(\phi)$ are the slopes to the curve of cumulative shortening across the prism. The curve constructed from values of $\phi$ (dashed curve of Fig. 6) shows a cumulative shortening of nearly $9 \mathrm{~km}$ at SP 1600 . Extrapolation of the curve to SP 1550 passes very close to the value derived from a total mass balance as might be expected because both methods are based on common assumptions. Despite the uncertainties of measurement and the assumptions concerning input volume, estimates using both indirect methods also agree quite well with the cumulative shortening obtained by summing the shortening on individual thrusts and within thrust sheets.

\section{INSTANTANEOUS DISTRIBUTION OF DEFORMATION}

To this point I have avoided a discussion of relationships between deformation and time, because the available age estimates are poor and I have attempted to develop arguments with as few assumptions as possible. However, one of the more important questions concerning subduction-related deformation is the instantaneous distribution of horizontal shortening across the forearc. The values of shortening derived in the previous section reflect cumulative deformation that has been proceed- 
ing within masses of sediment for increasing periods of time as they move to more arcward positions, and there is no reason to assume that the rate of deformation in any sediment mass remains constant.

The well-defined spatial distribution of deformation in the toe of the accretionary prism suggests that methods of continuum mechanics might be used to determine instantaneous rates of deformation. In such an approach the incoming sediment mass is viewed as a material flux that changes its density and height during deformation in the prism (Fig. 7). The applicable form of the continuity equation is:

$$
\frac{\partial(\rho h)}{\partial t}+\frac{\partial\left(\rho u_{x} h\right)}{\partial x}=0
$$

where $\rho$ is the average dry bulk density at distance $x, h$ is the thickness of the prism above the décollement, and $u_{x}$ is the particle velocity at $x$. In this simplified two-dimensional flow, $u_{x}$ is assumed to be constant with depth, and porosity variations in the vertical dimension are avoided by use of average values for columnar elements of the accretionary prism.

This equation approximates conditions in the Nankai prism because flow across the discontinuity beneath the region of interest is minimal and because the local loss of material through erosion over the thrust toes and transport to the trench floor is to a large extent counterbalanced by sedimentation on the rest of the slope. The most critical assumption necessary to permit a solution is that the geometry of the toe of the prism is constant over the time period of interest. In detail this simplification is not true in that the thickness of the input section has decreased with time and the subduction rate has probably increased (Karig and Angevine, this volume). However, these two parameters are inversely coupled through the input volume, which probably has changed only slowly. Furthermore, we are interested in a time interval of only 1 to $1.5 \mathrm{Ma}$.

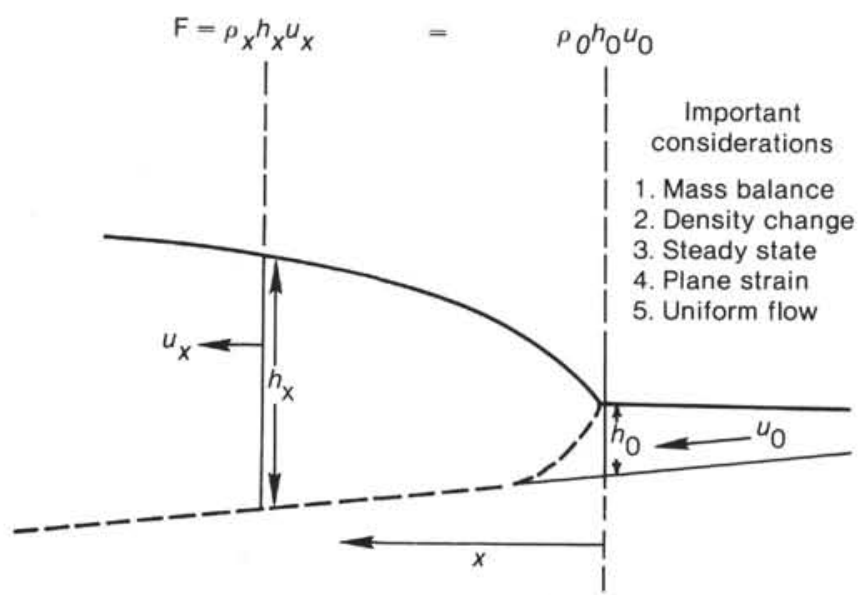

Figure 7. A simple continuum model of mass flow through the toe of an accretionary prism with a steady-state geometry. The reference frame is fixed to the prism geometry. The assumptions and other considerations are more fully discussed in the text.
In the case of a steady-state geometry the continuity equation reduces to

$$
\frac{\partial\left(\rho u_{x} h\right)}{\partial x}=0
$$

Integration yields $\rho u_{x}=\rho_{0} u_{0} h_{0}$, where the zero subscript refers to values of the input section. In particular, in the reference frame fixed to the geometry of the accretionary prism, $u$ is the subduction rate. As $x$ increases, $u_{x}$ approaches $u_{a}$, the outgrowth rate of the prism with respect to the plate interior.

The instantaneous distribution of shortening is equivalent to $\partial u_{x} / \partial x$, where $u_{x}=\partial x_{p} / \partial t$, the velocity of a particle at position $x_{p}$. In the steady state any particle at this position will have this time-independent velocity.

Values of $u_{x}$ can be obtained two ways, both of which depend on the geometry and porosity distributions calculated earlier. The first uses the continuity equation.

$$
u_{x}=\left(\frac{\rho_{0} h_{0}}{\rho h}\right) u_{0} \text { (Fig. 7). }
$$

Because the reference frame for deformation is fixed to the prism, $u_{x}$ approaches the outgrowth rate as $x$ becomes large. This requires substitution of $u_{x}+u_{a}$ for $u_{x}$ and $u_{0}+u_{\mathrm{a}}$ for $u_{0}$, in order that the ratio of velocities (and thus fractional deformation) varies between 0 and 1. To simplify the following derivations, this change of reference form is made at the final stage of the calculation and both frames are shown on Figure 8. The ratio of densities times heights $(\rho h)$ is numerically identical to the ratios of DRE volumes at these points, so values of $u_{x}$ can be obtained immediately from the previous measurements. The slope of the plot of $u_{x}$ against $x$ is then $\partial u_{x} / \partial x$. However, because the magnitudes of $u_{x}$ reflect

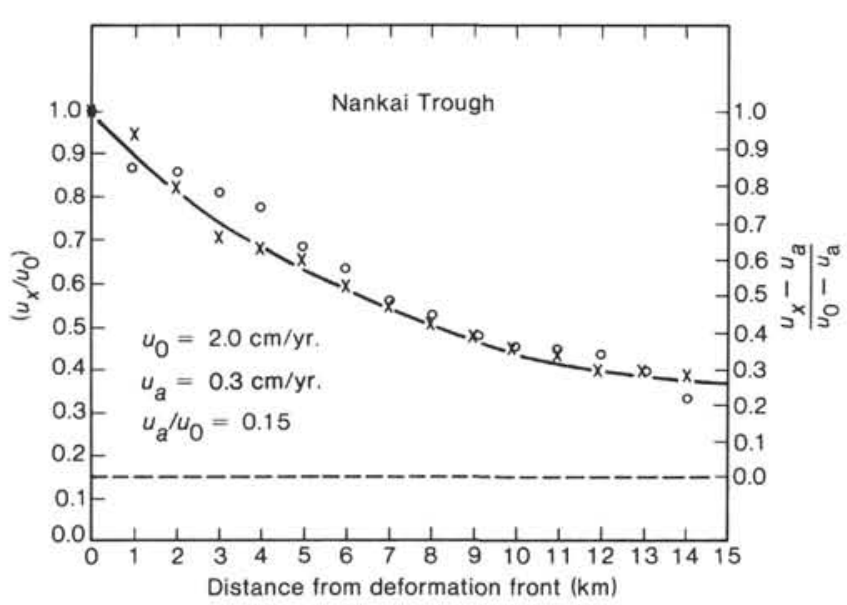

Figure 8. Distribution of relative shortening across the toe of the Nankai accretionary prism. Values of $u_{x} / u_{0}$ are the normalized ratio of the horizontal particle velocity divided by the subduction velocity $\left(u_{0}\right)$. Thus half the instantaneous shortening occurs within $8 \mathrm{~km}$ of the deformation front. The crosses represent values derived from the continuity equation, whereas the circles are values derived from the relationship $\partial \phi / \partial t=-\partial u / \partial x$ (see text for details). 
the assumed subduction rate $\left(u_{0}\right)$, normalized values $u_{x}$ ' $u_{0}$ can be plotted against position $(x)$, which show the distribution of relative shortening, independent of subduction rate (Fig. 8).

A second approach uses another definition of the horizontal shortening ratio, $\phi_{x}=-\partial x_{p} / \partial x$. If this formulation is differentiated with respect to time, it is equivalent to the derivative of $u_{x}$ with respect to $x$ :

$\partial \phi / \partial t=-\partial u / \partial x$, which can be rewritten as $\partial u / \partial x=$ $-u \partial \phi / \partial x$ (Henceforth $\phi$ without subscript will be assumed to be $\phi_{x}$ ).

Recasting, $\quad \frac{\partial \phi}{\partial x}=-\frac{1}{u} \frac{\partial u}{\partial x}=\frac{-\partial \ln u}{\partial x}$.

Upon integration, $\phi=-\ln u+\mathrm{c}$, but at $x=0, \phi=0$ and $u=u_{0}$. Thus

$$
\phi=\ln \frac{u_{0}}{u} \text { or } u=u_{0} \mathrm{e}^{-\phi} .
$$

With values of $\phi$ taken from a smoothed curve fit to observed cumulative shortening (Fig. 8), this equation gives values of $u_{x} / u_{0}$ very close to those of the first approach (Fig. 7), thus strengthening the plausibility of the continuous mechanics assumptions.

Both methods show that $u_{x} / u_{0}$ and $\partial\left(u_{x} / u_{0}\right) / \partial x$ decrease arcward across the toe of the Nankai accretionary prism (Fig. 8). For the assumption of a constant sediment input rate, about one-third of the instantaneous shortening caused by subduction is absorbed in the protothrust zone (about one-fourth if the observed rather than smoothed curve is used), and nearly three-fourths occur less than $15 \mathrm{~km}$ from the deformation front (Fig. 8 ). The other one-fourth is presumably spread in an arcward-decreasing distribution across the rest of the lower inner slope. However, arcward extrapolation of the continuity assumption is not warranted because of the probability of subcretion and significant slope sedimentation.

\section{DISCUSSION}

Observations concerning deformation within the toe of the Nankai accretionary prism have implications for a number of structural and sedimentologic problems in the trench setting. They also lead to the comparison of behavior of this arc with others, especially those now accreting sediments.

Deformation across the toe of the Nankai slope can be quantified and then analyzed using methods of continuum mechanics. The resulting estimates show that whereas cumulative deformation increases arcward across the prism, the instantaneous rate of shortening is greatest in the protothrust zone and frontal thrust area, where only subtle structures have developed. The distribution of deformation in the Nankai prism is thus similar to that deduced in the Sunda (Karig et al., 1980) and northern Middle America (Moore et al., 1979) trenches from less quantitative constraints.

The quantitative results from the Nankai Trough also can be used to differentiate between the slow $(\leq 2 \mathrm{~cm} /$ yr.) subduction rates proposed by Karig and Angevine (this volume) from the more rapid ( $>4 \mathrm{~cm} / \mathrm{yr}$.) rates of Seno (1977) and others. The slope of the normalized velocity curve (Fig. 8) is

$$
\frac{\partial\left(\frac{u_{x}}{u_{0}}\right)}{\partial x}
$$

for all subduction rates $\left(u_{0}\right)$. Thus, if we can determine the value of the slope at some point $(x)$ from geologic observations, we can the calculate a subduction rate.

In the protothrust zone, the trench-fill offlap relationships indicate that the deformation front was near SP 1800 between 0.4 and $0.45 \mathrm{Ma}$ ago. The observed and calculated (or smoothed) curves of $\phi$ with respect to position (the slope of curves on Fig. 6) differ significantly here because of the discontinuity caused by the frontal thrust. The smoothed value of $\phi$ at SP 1800 is 0.45 . Thus the change in horizontal shortening rate with respect to time, $\partial \phi / \partial t \simeq 1 \mathrm{Ma}^{-1}$, can be compared with values of $\partial u / \partial x$ calculated at SP 1800 for various subduction rates. At $2 \mathrm{~cm} / \mathrm{yr} . \partial u / \partial x=1.15 \mathrm{Ma}^{-1}$, whereas $\partial u / \partial x$ at a $4.5 \mathrm{~cm} / \mathrm{yr}$. subduction rate would be 2.33 $\mathrm{Ma}^{-1}$. If, instead, the local observed value of $\phi(0.24)$ at SP 1800 is used, together with the local value of $\partial u / \partial x$ $(0.56)$, a very similar result is obtained. Clearly, this exercise strongly supports subduction rates of $2 \mathrm{~cm} / \mathrm{yr}$. or even less.

The seismic reflection profile suggests that deformation in the toe of the Nankai prism occurs in two forms: bedding-plane step thrusts and more diffuse mechanisms, generating more homogeneous tectonic thickening throughout the thrust sheet. The mechanism, or mechanisms, responsible for diffuse deformation is not resolved by seismic profiling, nor was it obvious in the drill cores. It very well may result from several processes, including small-scale thrusting and folding. Stratal thickening may also result from the conjugate set of shear surfaces encountered near the thrust fault at Site 583 (Lundberg and Karig, this volume). In both Sites 583 and 298 there was also horizontal shortening on steeply dipping dislocation or kink bands (Lundberg and Karig, this volume). The seismically defined $60^{\circ}$ northward-dipping discontinuities within the protothrust zone may be a related form of deformation in that they also have the geometry of reverse kink bands. These steeply dipping discontinuities are, to date, unique to the Nankai system, but probably only because reflection profiles across other arcs showing protothrust zones (e.g., Sunda) have not been as successfully migrated.

The most obvious large-scale structural process near the toe of the Nankai prism is bedding-plane step thrusting. In the best-resolved example of the frontal thrust, all the expected geometric features, in near quantitative dimensions, are observed. The step has a dip very close to $30^{\circ}$ and has quite sharp corners. There are minor imbricate faults producing some fault plane rotation, but the thrust does not appear to have evolved from one of the $60^{\circ}$-dipping discontinuities.

Displacement deduced from the geometries of thrust structures (e.g., ramp corner displacements) in the $15-\mathrm{km}$ 
sector with adequate reflection coherence are consistent with displacements derived from paleontologic studies and mass balance calculations. All bed rotation and fold structures seen in the prism back to SP 1600 can be explained as the result of bedding-plane step thrusting on ramps with initial dips of 20 to $30^{\circ}$. Contrary to earlier interpretations (Moore and Karig, 1976), large-scale folding, as displayed in the Makran and reconstructed in Barbados, does not occur in the toe of the Nankai prism.

Seismically identifiable thrust faults in the Nankai prism appear to have had an original spacing of about $3 \mathrm{~km}$. However, these individual thrust sheets quickly amalgamate into compound units 5-7 km wide, as interpreted from reflectors seaward of SP 1600 and from the spacing of the thrust ridges seen on a new bathymetric map (Kagami, this volume). Apparently thrusts bounding the compound units have continued to be active and to maintain a topographic relief, whereas the internal thrusts have degenerated.

Each of these compound-thrust sheets is itself wedgeshaped, reflecting both the original trench-wedge geometry and progressive arcward tectonic thickening. This latter process is illustrated by the preferential preservation of seismic coherence in the toe area of each thrust sheet.

The arcward steepening of strata within the seismically coherent toe of the prism is interpreted to continue across the lower slope until dips approach the vertical beneath the forearc basin and in the Shimanto complex. Continuous rotation and/or steepening of bedding arcward across the prism has been disputed by Hamilton (1979), Shipley (1982), and others, either on conceptual grounds or from seismic and drilling data. The $30^{\circ}$ maximum dip postulated by Hamilton (1979) is contradicted both by the seismic data and by the structure of the emergent (Shimanto) parts of the Nankai accretionary prism. That this continued steepening is not unique to the Nankai prism is established by modal $60-70^{\circ}$ arcward dips of strata on Nias, an emergent section of the Sunda accretionary prism (Moore and Karig, 1980). Very steep stratal dips are also typical of accreted strata in accretionary prisms of the eastern Aleutian (e.g., Byrne, 1982) and Makran (e.g., Ahmed, 1969) arcs. The limited rotation observed in the Middle America forearc (Shipley, 1982) might alternatively result from a very narrow accretionary prism, backed against rigid continental crust; there may be no room for unconstrained rotation in such a geometry.

Steepening of accreted strata across the prism, which probably absorbs much of the remaining one-fourth of the subduction rate, is partly caused by continued rotation of thrust packets as reflected in the rotation of overlying slope basin sediments. Additional steepening might be attributed to isoclinal folding, which appears to be a common structural style in the youngest exposed Shimanto complex. Such folds, with amplitudes of at least a few hundred meters, are not observed in the toe of the prism, but may be occurring beneath the more arcward sections of the lower slope, where seismically resolvable open folding of the cover of slope sediments can be seen on several proprietary seismic profiles.
All structures within the toe of accretionary prism terminate downward against the subduction décollement, which can be clearly tracked, from the geometries of bounding strata back to SP 1350 . This décollement initiates near the base of the trench fill beneath the protothrust zone, but drops into the upper hemipelagic sequences of the Shikoku Basin at the basal thrust and remains just above the Pliocene turbidites at least to SP 1300 (unmigrated section of Nasu et al., 1982). Although the stratigraphic position of the décollement is masked by the water-bottom multiple near SP 1300 , the basement reflector can be traced continuously arcward for at least another $10 \mathrm{~km}$. On several other seismic lines across the Nankai prism, basement reflectors extend smoothly and continuously for over $50 \mathrm{~km}$ (e.g., Aoki et al., 1984), suggesting little or no basement involvement in subcretion over this interval. Several examples of basement undulations on the Nankai profiles that might be attributed to basement thrusting can better be explained by effects of incorrect assumed stacking velocities (Aoki et al., 1984) or by preexisting basement topography (as on Line N-55-1; Nasu et al., 1982).

What, then, can be deduced concerning the fate of the basal strata subducted beneath the toe of the prism? The strongest implications can be derived from a comparison of the DRE volume of the prism, north to the capes of Shikoku, where the age of accretion is near $30 \mathrm{Ma}$ (Karig, unpublished data), with the DRE input over this duration. This comparison indicates that, at average subduction rates of 1 to $4 \mathrm{~cm} / \mathrm{yr}$., there is more than enough volume to accommodate the sediment input. The excess volume might be accounted for by an older insular margin sediment prism or by igneous rock stripped from the descending ocean crust.

The pattern of deformation deduced for the Nankai prism leads to several implications concerning the postdepositional redistribution of sediment on the lower slope. First, stratal geometries interpreted from the reflection profile and biostratigraphic data both indicate far greater displacements on the thrust faults than does the surface relief. This interpretation leads to the conclusion that up to several hundred meters of sediment has locally been removed from the hanging-wall anticlines over the thrust faults. The process is qualitatively corroborated by the results of Hole 583B, which demonstrated that several tens of meters of section have already been removed from the toe of the basal thrust. Furthermore, if the displacements on the thrusts were determined from surface relief rather than from the structural geometries, the total shortening over the first $15 \mathrm{~km}$ of the prism would be far less than that calculated from the mass balance methods.

The material removed from the thrust toes probably now lies at several sites. Some has been redeposited as slope sediments, represented by the coarse clastic deposits in the uppermost sections of Holes 583, 583A, and probably Hole 298 of Leg 31 (Ingle, Karig, et al., 1975). Quite likely a fraction of the removed material returns to the trench as mass flow deposits, indistinguishable from primary trench deposits. Still another fraction may contribute to the excess mass of sediments at the toe of the 
frontal thrust. This mass appears to define a slump apron similar to, but smaller than, examples observed in the Sunda (Karig et al., 1980) and Makran (R. S. White, pers. comm., 1981) trenches. The irregular surface and internal seismic incoherence of these aprons suggest that they include highly deformed but unconsolidated sediments, resulting from both slumping and thrusting.

Slump aprons in all three arcs are observed only at the toe of the frontal thrust, despite the existence of larger and steeper thrusts upslope. This localization is attributed to the initial uplift of unconsolidated trench strata on the frontal thrust. Development of more stable slopes in stronger sediments along the older thrust toes would inhibit slump apron development. Slump aprons form extremely important rock units because they are overridden by continued thrusting during or very soon after their formation, leading to the superposition of tectonic shearing on "soft-sediment" deformation. This process would remove some of the confusion concerning the origin of mélange and explain the occurrence of mélange in tabular zones between less deformed strata (e.g., Moore and Karig, 1980).

No zones of mélange or strongly deformed sediments were recognized at Site 583, and there is no evidence for bedding plane extensional strain. Hole 583D penetrated the frontal thrust near a depth of $155 \mathrm{~m}$, but core recovery in this section was very poor and the sediments were quite unconsolidated. Nevertheless, Core 583D-13, closest to the suspected intersection, contained sand bodies suspended in mud; these bodies may be a result of drilling, but similar features in DSDP cores from the inner slope of the northern Middle America Trench were interpreted as structural in origin (Lundberg and Moore, 1982). The lack of deformation outside the thrust zones offers further support for arguments associating the intense deformation in accretionary prisms with faulting.

The heterogeneity of mechanical response to subduction implied by the distribution of deformation is mirrored by implied heterogeneity in physical properties. A sparsely documented but widely held opinion associates tectonism with a more rapid drop in porosity with depth in accretionary prisms than in normally consolidating basins (e.g., Carson, 1977). Seismic data from the Nankai accretionary prism generally support this concept (Fig. 4), but the distribution and mechanism of dewatering within the prism toe are not at all straightforward.

Comparison of porosity-depth profiles at Hole 298 with those at sites in the Shikoku (Site 297) and Japan (Site 299) basins led to an interpretation of anomalously rapid dewatering in the prism toe (Moore and Karig, 1976). More continuous and detailed analyses comparing the identical stratigraphic sections revealed that the porosities in the frontal thrust sheet (Sites 583, 298) are only slightly less than those at equivalent depths in the undeformed trench section at Site 582 (Bray and Karig, this volume). Differences in porosity of $2-3 \%$ at depths greater than $350 \mathrm{~m}$ are less than the dewatering either observed in the Lesser Antilles arc (J.C. Moore, pers. comm., 1983) and Cascade arc (Carson, 1977) or measured in modeling experiments (Carson and Berglund, in press). It might then be asked whether dewatering is a diffuse, relatively homogeneous process or a more discontinuous one.

Implications bearing on this question can be drawn from the observation that the first few thrust faults in the Nankai prism are marked by well-defined seismic reflectors. This is an unusual characteristic for most thrust faults because, as in the Nankai examples, there are no consistent lithologic differences across the fault that would give rise to the impedance contrasts necessary to produce a reflection.

Could these reflections be the result of strong localized dewatering within the fault zone producing higher densities and seismic velocities? This explanation finds support in soil mechanics studies, which demonstrate greater porosity decreases under deviatoric stress than under hydrostatic stresses (e.g., Schofield and Worth, 1976). It remains to be seen whether this "shear dewatering" continues at higher stress and lower porosity ranges than those used in soil mechanics. Some observational support for the efficacy of this process in accretionary prisms is the local porosity minimum associated with a zone of suspected strong deformation in Hole 488 on the northern Middle American forearc (Shepard et al., 1982).

Dewatering might occur initially along zones of shear, of which the décollement and dipping thrusts are the most obvious. These faults might be not only zones of preferential dewatering but also avenues of preferential water egress from dewatering regions at depth. This seeming contradiction is resolved by the lack of close dependence between porosity and permeability, which might be fracture induced along the fault zones. Of course, the pore pressures at depth could remain high during the decrease in porosity.

\section{CONCLUSIONS}

Although the recent drilling in the Nankai Trough failed to accomplish many of its objectives, it did show quite clearly that earlier interpretations concerning the structural style were in error. Thrust faulting, remarkably similar in geometry to that of foreland thrust belts, rather than recumbent folding, dominates the deformation at the prism toe. The occurrence of this structural style, in both semiconsolidated and highly lithified sediments, suggests that heterogeneities in physical and mechanical properties rather than the magnitude of rock strength are the controlling properties.

Distribution of deformation in the Nankai prism is quite similar to that in other accreting forearcs, with the greatest instantaneous deformation near the prism toe. This deformational pattern, coupled with the apparent concentration of surficial gravitational structures at the toe of the basal thrust, supports models of mélange formation along active thrust zones.

The Nankai program, in both its successes and failures, spotlights the need for continued quantitative studies of the properties of subduction zones. Critical data with which to test the ideas and values presented here could be obtained by additional deep-sea drilling in the Nankai Trough, particularly because the geologic and 
environmental factors have now been shown not to be serious problems.

\section{ACKNOWLEDGMENTS}

I am particularly indebted to Donald Turcotte, who kept me from making too many errors during my foray into continuum mechanics. I also received thoughtful and constructive criticism from Casey Moore, Cynthia Bray, Richard Faas, George Planansky, and Richard Allmendinger. This work was indirectly supported by several grants from the National Science Foundation.

\section{REFERENCES}

Ahmed, S. S., 1969. Tertiary geology of part of South Makran, Baluchistan, West Pakistan. Am. Assoc. Petrol. Geol. Bull., 53:14801499.

Aoki, Y., Tamano, T., and Kato, S., 1984. Detail structure of the Nankai Trough from migrated seismic sections. Am. Assoc. Petrol. Geol. Mem., 34:309-324.

Athy, L. F., 1930. Density, porosity and compaction of sedimentary rocks. Am. Assoc. Petrol. Geol. Bull., 14:25-35.

Bray, C. J., and Karig, D. E., 1985. Porosities in sediments in accretionary prisms and some implications for dewatering processes. $J$. Geophys. Res., 90:768-778.

Byrne, T., 1982. Structural evolution of coherent terranes in the Ghost Rocks Formation, Kodiak Island, Alaska. In Leggett, J. K., (Ed.), Trench-Forearc Geology: Sedimentation and Tectonics on Modern and Ancient Active Plate Margins: London (Geol. Soc. London), Spec. Publ., 10:229-242.

Carson, B., 1977. Tectonically-induced deformation of deep-sea sediments off Washington and northern Oregon. Mar. Geol., 24:289307.

Carson, B., and Berglund, P. L., in press. Sediment dewatering associated with subduction-accretion: experimental result. J. Geophys. Res.

Dahlstrom, C. D. A., 1977. Structural geology in the eastern margin of the Canadian Rocky Mountains. Wyoming Geol. Assoc. Guidebook, 29th Ann. Field Conf., pp. 407-439.

Hamilton, E. L., 1976. Variation of density and porosity with depth in deep sea sediments. J. Sediment. Petrol., 46:280-300. , 1978. Sound velocity-density relations in sea floor sediments and rocks. J. Acoust. Soc. Am., 63:366-377.

1980. Geoacoustic modelling of the sea floor. J. Acoust. Soc. Am., 68:1313-1340.

Hamilton, W., 1979. Tectonics of the Indonesian Region: Boulder, Colorado (U.S. Geol. Surv.), Prof. Paper 1078.

Hsü, K. J., and Ryan, W. B. F., 1972. Summary of the evidence for extensional and compressional tectonics in the Mediterranean. In Ryan, W. B. F., Hsü, K. J., et al., Init. Repts. DSDP, 13: Washington (U.S. Govt. Printing Office), 1011-1019.

Ingle, J. C., Jr., Karig, D. E., et al., 1975. Site 298. In Karig, D. E., Ingle, J. C., Jr., et al., Init. Repts. DSDP, 31: Washington (U.S. Govt. Printing Office), 67-130.

Karig, D. E., Moore, G. F., Curray, J. R., and Lawrence, M. B., 1980. Morphology and shallow structure of the lower trench slope off
Nias Island, Indonesia. In Hayes D. E. (Ed), Tectonic and Geologic evolution of Southeast Asian Seas and Island: Washington (Am. Geophys. Union), Geophysical Monograph 23:179-208.

Lundberg, N., and Moore, J. C., 1982. Structural features of the Middle America Trench slope off southern Mexico, Deep Sea Drilling Project, Leg 66. In Watkins, J. S., Moore, J. C., et al., Init. Repts. DSDP, 66: Washington (U.S. Govt. Printing Office) 793-814.

Means, W. D., 1976. Stress and Strain: New York (Springer-Verlag).

Moore, G. F., and Karig, D. E., 1980. Structural Geology of Nias Island, Indonesia. Am. J. Sci., 280:193-223.

Moore, J. C., and Karig, D. E., 1976. Sedimentology structural geology, and tectonics of the Shikoku subduction zone, southwest Japan Geol. Soc. Am. Bull., 87:1259-1268.

Moore, J. C., Watkins, J., and Scientific Staff, 1979. Progressive accretion in the Middle America Trench, southern Mexico. Nature, 281:638-642.

Nasu, N., Tomoda, Y., Kobayashi, K., Kagami, H., et al., 1982. Multichannel Seismic Reflection Data across Nankai Trough: Tokyo (Ocean Research Institute, University of Tokyo), IPOD-Japan Basic Data Series, No. 4.

Schofield, A. N., and Wroth, C. P., 1976. Critical State Soil Mechanics: London (McGraw Hill).

Seno, T., 1977. The instantaneous rotation vector of the Philippine Sea Plate relative to the Eurasian Plate. Tectonophysics, 42:209-226.

Shepard, L. E., Bryant, W. R., and Chiou, W. A., 1982. Geotechnical properties of Middle America Trench sediments, Deep Sea Drilling Project Leg 66. In Watkins, J. S., Moore, J. C., et al., Init. Repts. DSDP, 66: Washington (U.S. Govt. Printing Office), 475-504.

Shepard, L. E., and McMillen, K. J., 1982. Sedimentation rates of the southern Mexico continental margin, Deep Sea Drilling Project Leg 66. In Watkins, J. S., Moore, J. C., et al., Init. Repts. DSDP, 66: Washington (U.S. Govt. Printing Office), 445-451.

Shipley, T. H., 1982. Seismic facies and structural framework of the southern Mexico continental margin. In Watkins, J. S., Moore, J. C., et al., Init. Repts. DSDP, 66: Washington (U.S. Govt. Printing Office), 775-790.

Sigurdsson, H., Sparks, R., Carey, S., and Huang, T., 1980. Volcanogenic sedimentation in the Lesser Antilles Arc. J. Geol., 88:523-540.

Taira, A., Okada, H., Whitaker, J. H. McD., and Smith, A. J., 1982. The Shimanto belt of Japan: Cretaceous lower Miocene active margin sedimentation. In Leggett, J. K., (Ed.), Trench-Forearc Geology: Sedimentation and Tectonics on Modern and Ancient Active Place Margins: London (Geol. Soc. London), Spec. Publ., 10:5-26.

Taira, A., Tashiro, M., Okamura, M., and Katto, J., 1980. The geology of the Shimanto Belt in Kochi Prefecture, Shikoku, Japan. In Taira, A., and Tashiro, M. (Eds.), Geology and Paleontology of the Shimanto Belt: Kochi (Rinya-Kosakai Press), pp. 319-389.

Yoshii, T., Ludwig, W. J., Den, N., Murauchi, S., Ewing, M., Hotta, A., Buhl, P., Asanama, T., and Sakajiri, N., 1973. Structure of Southwest Japan Margin off Shikoku. J. Geophys. Res., 78:25172525 .

Date of Initial Receipt: 31 August 1983

Date of Acceptance: 25 February 1985 